\title{
ULTRASOUND-GUIDED CENTRAL VEIN CANNULATION
}

\author{
Vladan Cvetanovići ${ }^{1}$ Ines Veselinović1, Vesna Dinić1, Aleksandar Nikolićc ${ }^{1}$, Milena Stojanović1, \\ Milica Marković1 ${ }^{1}$ Marko Gmijović ${ }^{2}$
}

\begin{abstract}
Cannulation of large venous blood vessels is an important aspect of treating critically ill patients in terms of fluid administration, medication, parenteral nutrition, and monitoring. A conventional technique that uses superficial anatomy and palpation to identify large blood vessels before cannulation is based on the presumed localization of blood vessels, identification of anatomical features on the skin, and blind needle insertion until the time of blood aspiration. This technique is associated with a higher likelihood of failure, requiring more attempts and more complications. Ultrasound-guided vascular access provides a greater percentage of overall success as well as the success of the first cannulation attempt, faster vascular access, patient satisfaction and fewer complications.
\end{abstract}

Acta Medica Medianae 2021;60(3):72-79.

Key words: ultrasound, central venous catheters, cannulation

\author{
${ }^{1}$ University Clinical Center Niš, Clinic for Anesthesia and \\ Intensive Care, Niš, Serbia \\ Serbia \\ Contact: Vladan Cvetanović \\ 48 Dr Zoran Djindjić Blvd., 18000 Niš, Serbia \\ E-mail: vladan.cvetanovic@gmail.com
}

${ }^{2}$ University Clinical Center Niš, Digestive Surgery Clinic, Niš, fistula formation, venous air embolism, nerve injury, intraluminal dissection. Depending on the site of puncture, the most common complication in Internal Jugular vein (IJV) cannulation is arterial puncture and hematoma formation, while in Subclavian vein (SV) cannulation it is pneumothorax (3).

The proportion of complications is increasing exponentially in procedures performed by less experienced physicians, in patients with complex anatomy such as obesity or cachectic, in emergency settings cannulation, and in patients with comorbidities such as coagulopathies or the presence of pulmonary emphysema.

Ultrasound was introduced into clinical practice in the early 70's and is one of the most revolutionary methods ever in medicine. Already in 1978, ultrasound-guided central venous catheterization has been described as an effective technique for reducing the percentage of mechanical complications (4). The advances in computer technology have made ultrasound affordable, portable and with many indications for use in intensive care units. Since the beginning of the $21^{\text {st }}$ century, several national health agencies have published guidelines that strongly support the use of ultrasound $(5,6)$. These recommendations are based on studies that have shown a significant decrease in the percentage of failed punctures, a reduction in complications, and a shorter lead time $(7,8)$.

\section{Ultrasound principles for needle guided catheter placement}

Since the vascular structures are superficially positioned, a linear probe of high frequency $(7-10 \mathrm{~Hz})$ is used as it provides better resolution, with the 
choice of preset settings corresponding to the arterial or venous blood vessel. The ultrasound modalities for visualizing vascular and environmental structures includes two-dimensional images (2D) as well as Color Doppler (9-12), and the image of vascular structures is visualized in the short axis (SA) or long axis of blood vessels ( LA) each with their own advantages. Operator's knowledge of probe orientation, on-screen orientation, ultrasound physics, and interpretation of 2D vascular lumen images and structures in the environment is essential. Operators are required to coordinate handto-eye on screen images and manipulate the needle. This skill actually requires manual dexterity to perform the 3D task of placing the catheter in the appropriate blood vessel using and interpreting 2D images.

Probes typically have an indicator (Figure 1) that separates one from the other side, and the operator must identify which aspect of the screen corresponds to the indicator side. This can be done by moving the probe to one side while viewing the screen or by applying moderate external pressure to one side of the probe.

What is necessary when cannulating the vascular structures at all locations is for the probe to be oriented so that the structures below the left side of the probe should be on the left side of the screen. The probe indicator is turned to the left of the operator for visualization in the short axis, respectively to see the long axis of the blood vessels the probe rotates $90^{\circ}$ clockwise so that the probe indicator is located farthest from the operator (above) and again corresponds to the left side of the screen (Figure 1).

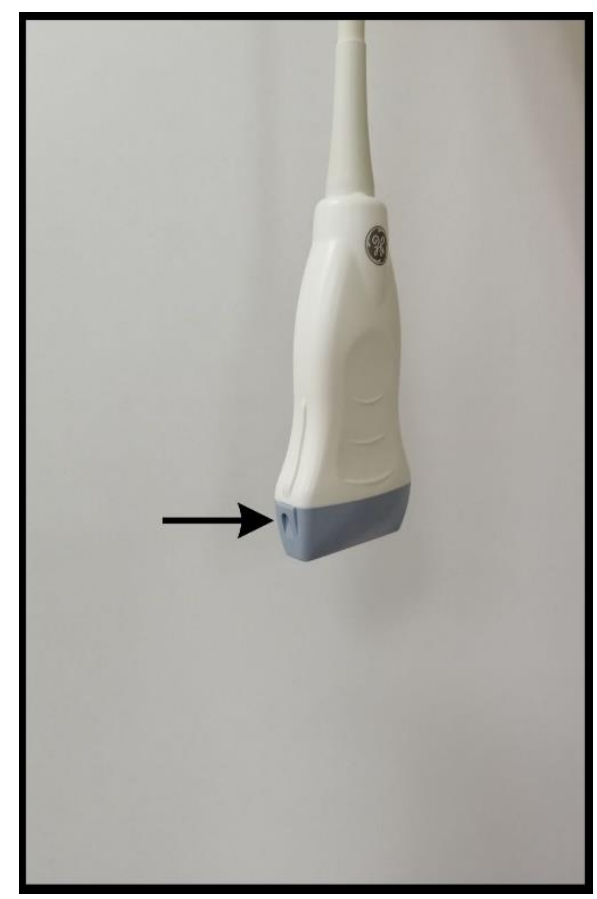

Figure 1. Linear probe with indicator
At the intersection in the short axis (Figure 2), the venous blood vessels are more oval, have an anechogenic content, their walls are thinner, fully compressible and have no pulsations. In contrast, arterial blood vessels are round, also have an anechogenic content, have a thicker wall, are poorly compressible and pulsate $(10,12)$. According to the cross section in the long axis, the blood vessels appear tubular (Figure 3).

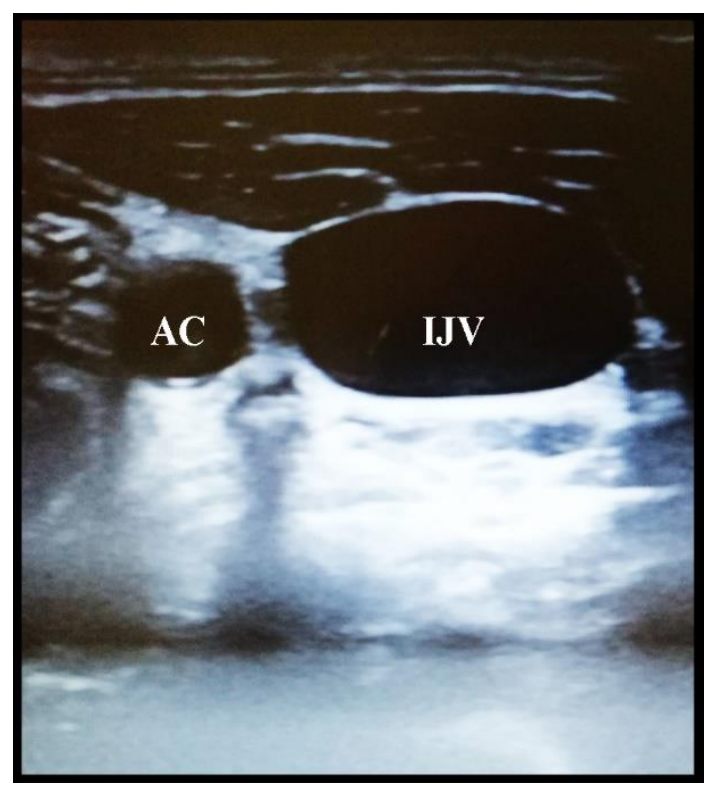

AC -Arteria Carotis

IJV-Internal Jugular vein

Figure 2. Short axis view

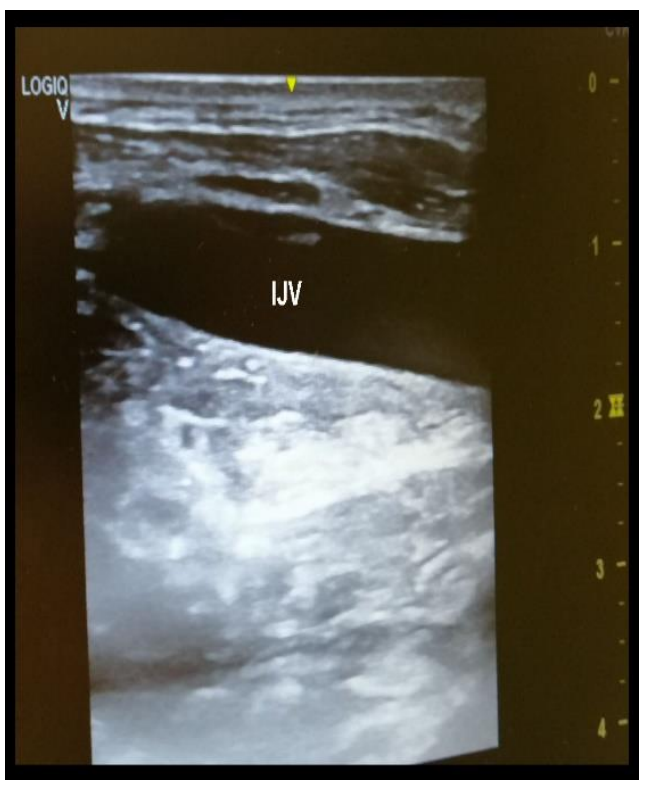

IJV-internal Jugular vein

Figure 3. Long axis view 
The veins are compressible, and valves can sometimes be visualized, with opening and closing movements. The arteries have no valves and are poorly compressible. The use of the Color Doppler spectral provides additional security in orientation because the veins have a phasic flow while the flow through the arteries is pulsatile (Figure 4).

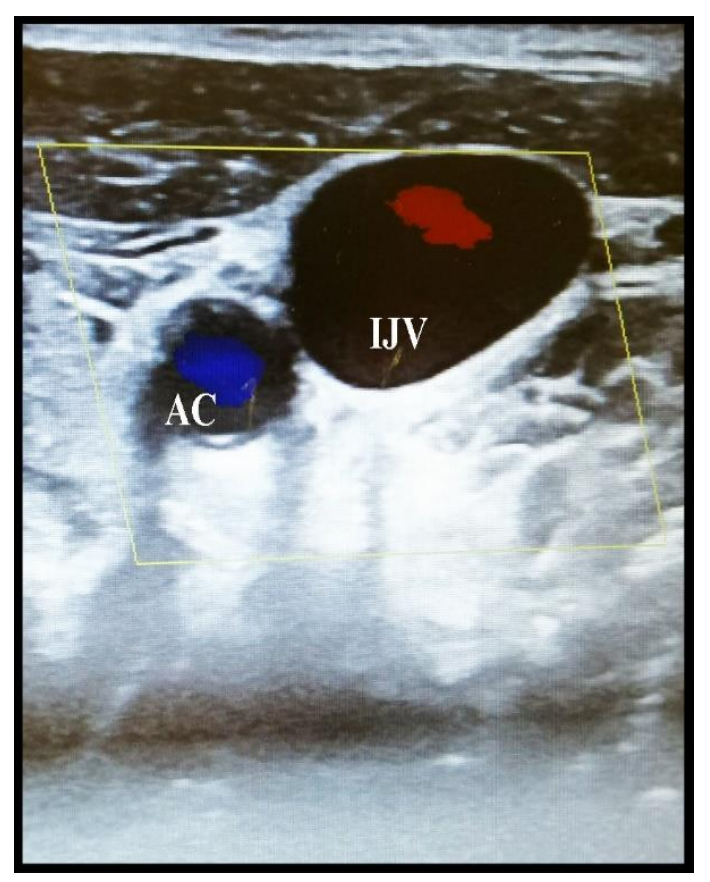

Figure 4. Use of Color Doppler

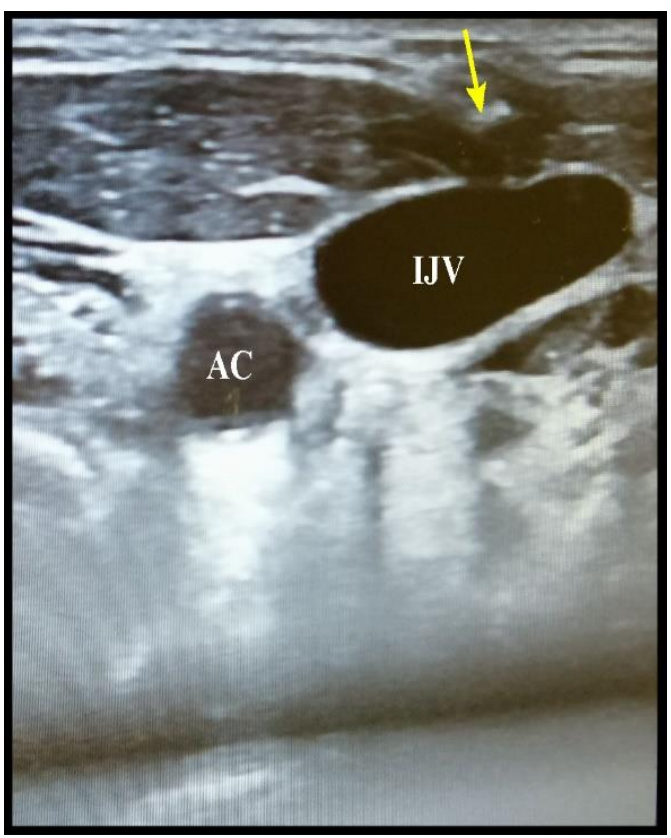

The yellow arrow marks the tip of the needle.
Vascular structures under ultrasound can be visualized in the so-called short axis (SA) or long axis (LA) of section through the blood vessel itself, and there is a hybrid approach between the two techniques so-called oblique. SA cannulation implies that a blood vessel is positioned in the center of the screen and that only the tip of the needle is visualized as a point on the screen (Figure 5) that advances toward the blood vessel. Since there are arteries near most central veins, the advantage of this technique is a better visualization of surrounding structures and the ability to have an arterial blood vessel on the screen at the same time, thus avoiding the unintentional puncture of the same. This technique is often referred to as "out of plane". When using this technique, indirect signs of cannulation are significant, such as moving supine structures as the needle progresses or pushing the anterior wall as the needle advances toward the blood vessel lumen. In the LA technique, the needle follows the path of the probe and ultrasound beam so that it is fully visualized, including the tip on its path from superficial structures to the blood vessel itself (Figure 6). The advantage of this technique is better visualization of the needle and depth of insertion, thus avoiding the insertion behind the target blood vessel. This technique is also known as "in plane" approach.

No matter what technique is used, it is crucial never to progress without needle visualization, and this is the most common cause of ultrasound complications.

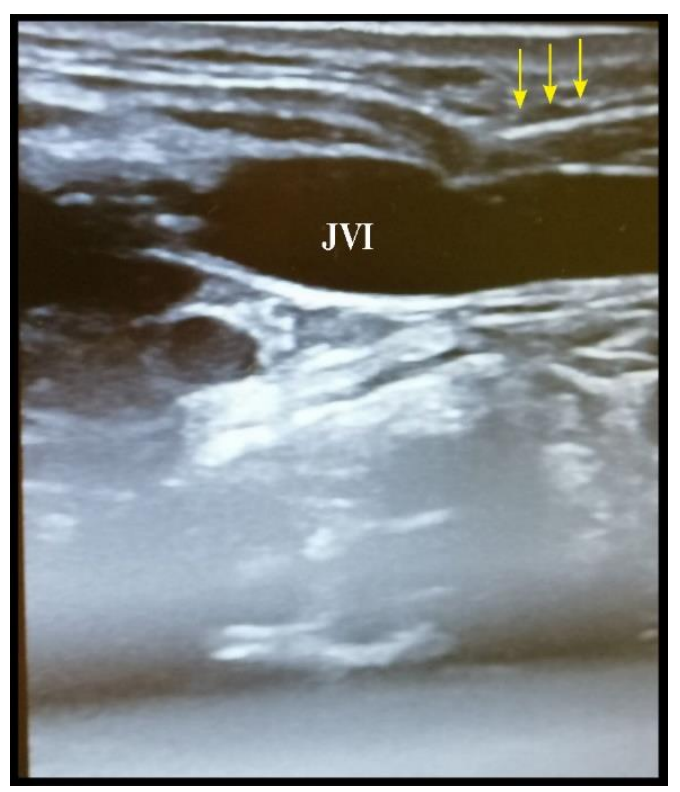

The yellow arrows mark the needle advancing to vessel lumen.

Figure 6. Cannulation in LA view

Figure 5. Cannulation in SA view 


\section{Static and dynamic approach to the identification of blood vessels}

There are two possible approaches when using ultrasound. The first approach practically involves the preliminary and exclusive visualization of structures in terms of anatomical identifications. This so-called "static" model is performed under nonsterile conditions, the position of the blood vessel is marked with a sterile marker, and the rest of the cannulation is performed using the traditional technique based on the features previously marked, so that the ultrasound serves only as a blood vessel locator. On the other hand there is so-called "dynamic" approach, or otherwise referred to as

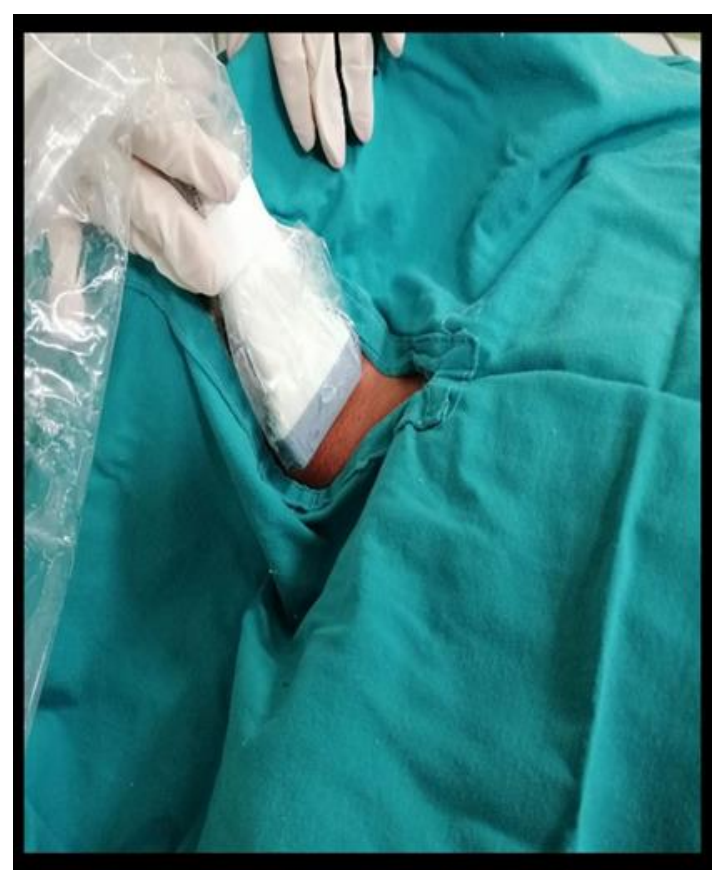

Figure 7. Sterile conditions of cannulation

It is important in this regard not to move the needle and probe at the same time. Successful cannulation of the blood vessel is confirmed by direct visualization of the needle entering the blood vessel and aspiration of blood into the syringe (Figure 9).

Further confirmation of successful cannulation is the ultrasound visualization of the wire or catheter real-time ultrasound cannulation. In the dynamic technique, sterile conditions related to the puncture site as well as the ultrasonic equipment used is of paramount importance (Figure 7).

The dynamic approach not only involves anatomical localization but also monitoring the needle progression to the blood vessel and confirming the position of the guide in the blood vessel. The nondominant hand holds the probe while the dominant hand controls the needle. The needle is inserted at an angle of $45^{\circ}$ relative to the skin (Figure 8 ), and as the needle progresses the probe moves gently, slides or tilts to keep the tip of the needle in the ultrasound beam all the time.

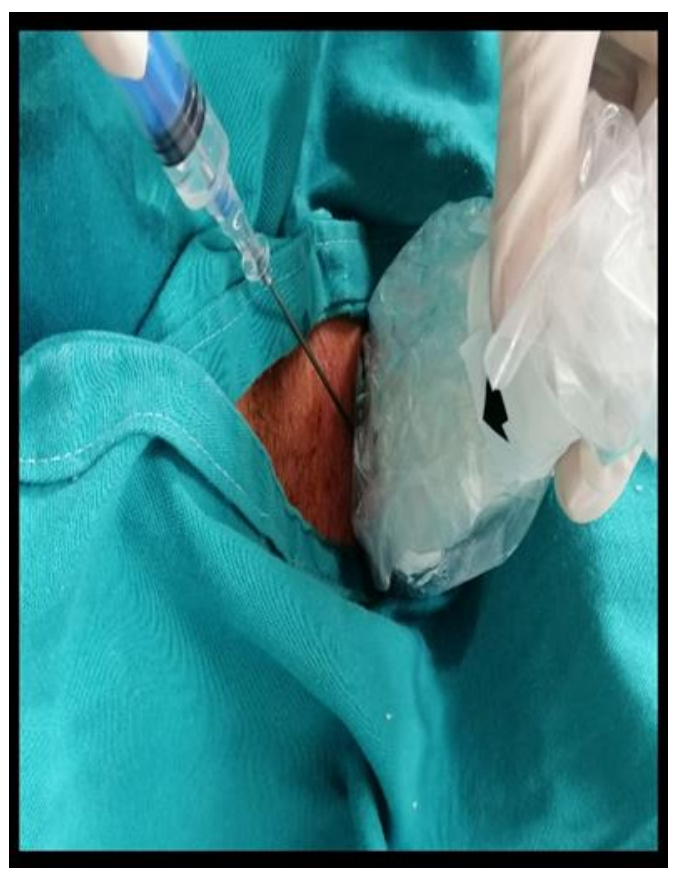

Figure 8. The needle is inserted at an angle of $45^{\circ}$

in the very lumen of the vessel at a cross-section in the long axis (Figure 10).

When comparing the static and dynamic techniques, certainly the dynamic one shows better results (13-17), but more importantly both ultrasound techniques are superior to the traditional technique that uses superficial anatomy (13-17). 


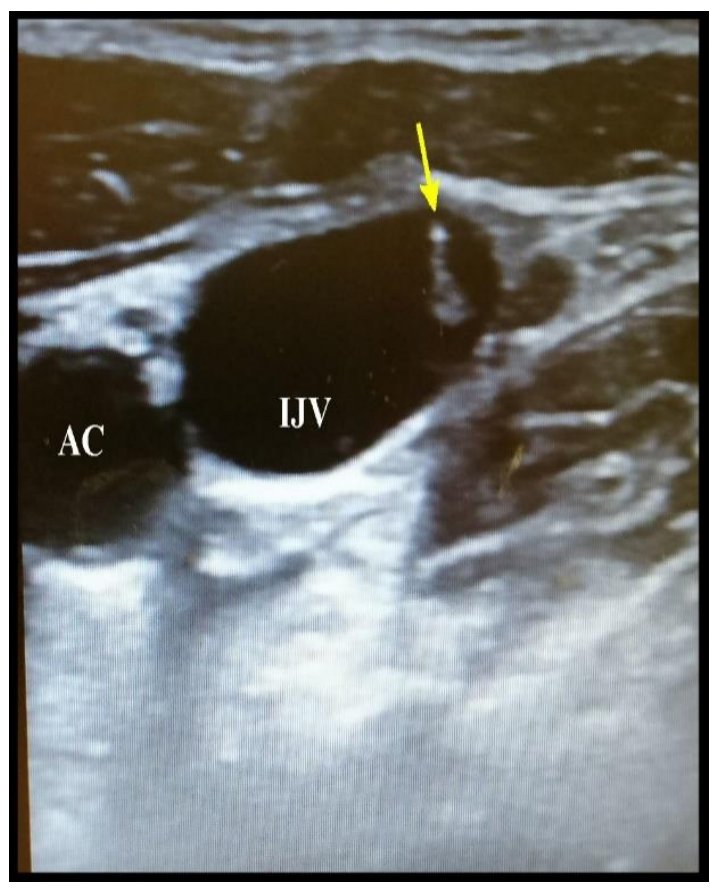

Figure 9. The yellow arrow marks the tip of the needle located in the lumen of the blood vessel

\section{Cannulation of the internal jugular vein}

In this paper, cannulation of the internal jugular vein will be described in detail, as it is the most common localization of central venous catheter cannulation. Anatomically, the internal jugular vein (IJV) exits the outer jugular foramen at the base of the skull posteriorly to the internal carotid artery (ICA), and proceeds caudally forward anterolateral to the internal carotid artery. So, generally speaking, the internal jugular vein is located anteriorly and laterally with respect to the carotid artery. Denys et al. (18) have shown that this theoretical anterolateral position of IJV with respect to ICA is in $92 \%$ of cases, $>1 \mathrm{~cm}$ lateral to carotid artery in $1 \%$ of cases, medially to ICA in $2 \%$ of patients, and even $5.5 \%$ outside the predicted anatomical pathway. There are also anatomical variations between the left and right jugular veins, with the diameter of the right being significantly larger than the diameter of the left in $65 \%$ of cases (19). The median diameter of the right jugular vein is $11.5 \mathrm{~mm}$, but may be less than $5 \mathrm{~mm}$ in $13-18 \%$ of patients $(19,20)$.

The traditional approach of IJV cannulation using anatomical structures is based on the identification of the triangle made out of the two heads of the sternocleidomastoid muscle and the clavicle. The needle is placed in the apex of the triangle and points towards the ipsilateral nipple, and with this position goes to meet the vein at a depth of 1.5-2 $\mathrm{cm}$ below the skin. Although the use of traditional techniques is considered a safe procedure in the hands of experienced clinicians, the proportion of

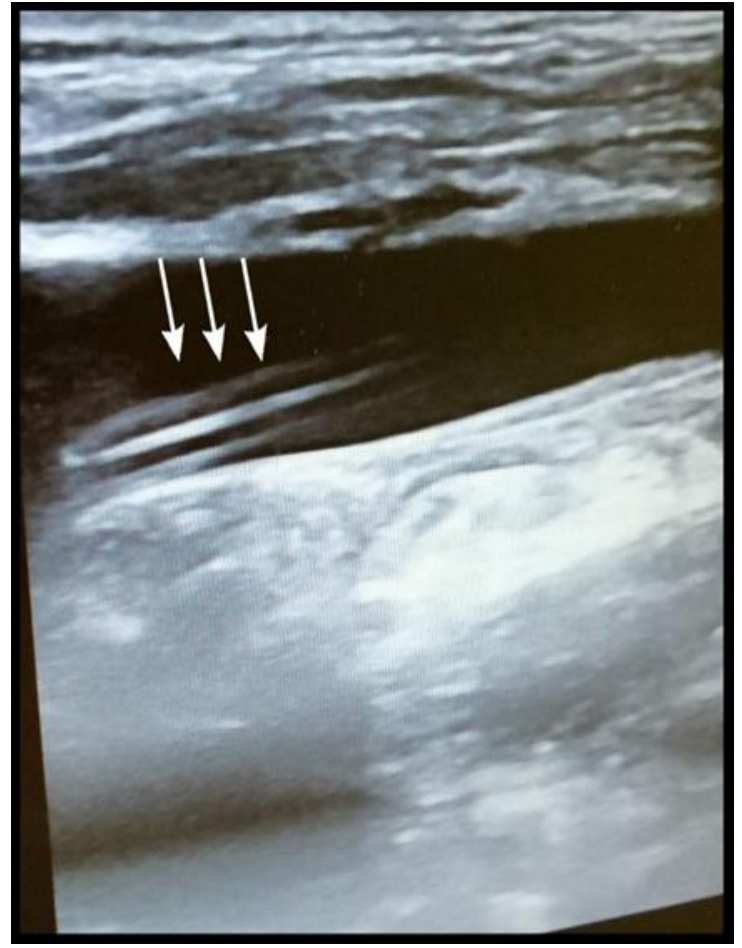

Figure 10. The catheter in the lumen of the blood vessel is marked with arrows

unsuccessful cannulation of $7-19 \%$ (21) is partly due to the inadequate correlation of external anatomical features with the location of the blood vessel (22). Also, after the first unsuccessful attempt, the success rate for each successive one decreases by $25 \%$, which in itself increases the incidence of complications, increases anxiety and discomfort in patients, and delays medication administration and monitoring setting in emergency situations.

There are studies whose research is based on establishing the anatomical relationship between IJV and ACI in terms of blood vessel overlap and the potential for puncture of the carotid artery (27-31). Sulek et al. (29) examined the effects of head rotation relative to the IJV and ACI position and concluded that the percentage of overlap increased as the head rotated contralaterally from the neutral position. Similar results were shown in another study where over half of the subjects experienced an overlap of $75 \%$ (27). In fact, rotating the head reduces the so-called "margin of safety" that represents the area from the middle of the IJV to the lateral wall of the ACI. This ratio between the margin of safety and the possibility of blood vessel overlap increases from $29 \%$ to $42 \%$ and $72 \%$, respectively, as the head rotates to the contralateral side from a neutral position to $45^{\circ}$ and $90^{\circ}$ (32). This overlap of blood vessels is most pronounced in obese patients with a BMI > 25kg/m².

Ultrasound also shows the size of the vein and the location, as well as anomalies, but also the patency because the vein thrombosis is an absolute contraindication for cannulation. 
Maneuvers that increase the diameter of the vein and therefore have potential success are the Trendelenburg position, which increases the area of the vein by $37 \%$ (33) and also Valsava maneuver can be used in patients not on mechanical ventilation (33).

Several studies have also shown the clear benefit of using ultrasound to sense fewer attempts and faster cannulation time (23-25). Such results are better visualization of the needle and surrounding structures, but also predict anatomical variations of blood vessels. In their research, Karakitos et al. compared ultrasound-guided cannulation with classical technique in 900 patients in JIL (26). Clinicians had either 10 years of experience in placement of vascular catheters without ultrasound, or five years of experience with ultrasound guidance. The success rate was $100 \%$ in the group with ultrasound versus $94 \%$, also faster pen time $17 \mathrm{sec}$. vs. $44 \mathrm{sec}$. and fewer attempts 1.1 vs. 2.6 attempts. Also with ultrasound, the total number of complications was reduced by $57 \%$, including the incidence of arterial puncture $1.1 \%$ vs. $10.6 \%$, hematoma $0.4 \%$ versus $8.4 \%$, pneumothorax $0 \%$ vs. $2.4 \%$ and infections $10.4 \%$ vs. $16 \%$. Similar results were demonstrated by Troianos et al. (10), the overall success rate increased from $96 \%$ to $100 \%$, but even more important was the first attempt success, which from $54 \%$ was raising to $73 \%$, with shorter cannulation times of $117 \mathrm{sec}$. compared to $61 \mathrm{sec}$. and a smaller rate of arterial puncture of $8.4 \%$ vs. $1.39 \%$.

\section{Cost-benefit analysis}

The analyses show an exponential increase in costs associated with central vein catheterization primarily in terms of complications and prolonged hospital stay. A UK-based economic model for the calculation of the costs associated with arterial puncture, pneumothorax and equipment use shows savings of almost $£ 4,000$ per 1000 procedures (34). Also in a similar study of the use of ultrasound in subclavian vein cannulation, the authors considered the number of sets consumed and found that without the use of ultrasound clinicians spent more than one set while those using ultrasound spent only one (34).

Regardless of the higher costs involved in procuring the device, cost-benefit analysis absolutely supports the use of ultrasound guided vessel cannulation techniques.

\section{Conclusion}

The use of ultrasound for the insertion of central venous catheters reduces mechanical and infectious complications, increases the success of the method but also the patient's satisfaction. With the availability of the device itself and adequate education, this technique should be adopted not only by young physicians but also by experienced clinicians in daily work, especially in the group of obese and edematous patients, patients with coagulation disorders and patients with severe anatomical orientation.

However, there is still a clinical non-acceptance of ultrasound in this indication. This is also evidenced by a large survey conducted by the American Society of Anesthesiologists, where as many as two-thirds of respondents never or very rarely use ultrasound, and only $15 \%$ use it regularly, although $75 \%$ have encountered complications (35).

Given the supporting evidence, it becomes very difficult to justify the non-use of ultrasound in cannulation of large blood vessels.

\section{References}

1. Seldinger SI. Catheter replacement of the needle in percutaneous arteriography; a new technique. Acta Radiologica 1953;39:368-76. [CrossRef] [PubMed]

2. Maecken T,Grau T. Ultrasound imaging in vascular access. Crit Care Med 2007;35(5 Suppl):S178-85. [CrossRef] [PubMed]

3. McGee DC, Gould MK. Preventing complications of central venous catheterization. N Engl J Med 2003; 348:1123-33 [CrossRef] [PubMed]
4. Hind D, Calvert N, McWilliams R, et al. Ultrasonic locating devices for central venous canulation: metaanalysis. BMJ 2003;327:361. [CrossRef] [PubMed]

5. Rothschild JM. Ultrasound guidance of central vein catheterization. In: Making healthcare safer: a critical analysis of patient safety practices. AHRQ Publication No 01-E058. Rockville, MD: Agency for Healthcare Research and Quality; 2001.pp.245-53. 
6. National Institute for Health and Clinical Excellence. NICE Technology Appraisal No guidance on the use of ultrasound locating devices for placing central venous catheters. Available at:

http://www.nice.org.uk/nicemedia/live/11474/ 32461/32461.pdf. Accessed October 17, 2011.

7. Rothschild JM. Ultrasound guidance of central vein catheterization. Making health care safer: A critical analysis of patient safety practices. Agency for Healthcare Research and Quality. URL available from: http://www.ahrq.gov/clinic/ptsafety/chap21.htm (accessed January 2010)

8. American College of Emergency Physicians. Use of ultrasound imaging by emergency physicians. Ann Emerg Med 2001;38:469-70. [CrossRef]

9. Lamperti $M$, Bodenham $A R$, Pittiruti $M$, Blaivas $M$, Augoustides JG, Elbarbary $M$, et al. International evidence-based recommendations on ultrasoundguided vascular access. Intensive Care Med 2012; 38: 1105-17. [CrossRef] [ PubMed]

10. Troianos CA, Hartman GS, Glas KE, Skubas NJ, Eberhardt RT, Walker JD, et al. Special articles: guidelines for performing ultrasound guided vascular cannulation: recommendations of the American Society of Echocardiography and the Society of Cardiovascular Anesthesiologists. Anesth Analg 2012; 114:46-72. [CrossRef] [PubMed]

11. Mahler SA, Massey G, Meskill L, Wang H, Arnold TC. Can we make the basilic vein larger? Maneuvers to facilitate ultrasound guided peripheral intravenous access: a prospective cross-sectional study. Int J Emerg Med 2011;4:53. [CrossRef] [PubMed]

12. AIUM practice parameter for the use of ultrasound to guide vascular access procedures. J Ultrasound Med. 2013;32:191-215. [CrossRef] [PubMed]

13. Costantino TG, Parikh AK, Satz WA, Fojtik JP. Ultrasonography-guided peripheral intravenous access versus traditional approaches in patients with difficult intravenous access. Ann Emerg Med 2005;46:456-61. [CrossRef] [PubMed]

14. Keyes LE, Frazee BW, Snoey ER, Simon BC, Christy D. Ultrasound-guided brachial and basilic vein cannulation in emergency department patients with difficult intravenous access. Ann Emerg Med 1999;34:711-4. [CrossRef] [PubMed]

15. Panebianco NL, Fredette JM, Szyld D, Sagalyn EB, Pines JM, Dean AJ. What you see (sonographically) is what you get: vein and patient characteristics associated with successful ultrasound-guided peripheral intravenous placement in patients with difficult access. Acad Emerg Med 2009;16:1298-303. [CrossRef] [PubMed]

16. Denys BG, Uretsky BF. Anatomical variations of internal jugular vein location: impact on central venous access. Crit Care Med 1991;19:1516-9. [CrossRef] [PubMed]

17. Samy Modeliar S, Sevestre MA, de Cagny B, Slama M. Ultrasound evaluation of central veins in the intensive care unit: effect of dynamic manoeuvres. Intensive Care Med 2008;34:333-8. [CrossRef] [PubMed]

18. Armstrong PJ, Sutherland R, Scott DH. The effect of position and different manoeuvres on internal jugular vein diameter size. Acta Anaesthesiol Scand 1994;38: 229-31. [CrossRef] [PubMed]

19. Sznajder JI, Zveibil FR, Bitterman $H$, Weiner $P$, Bursztein $S$. Central vein catheterization: failure and complication rates by three percutaneous approaches. Arch Intern Med 1986;146:259-61.

[CrossRef] [PubMed]
20. Gallieni M. Central venous catheterization of dialysis patients. J Vasc Access 2000;1:10-4.

[CrossRef] [PubMed]

21. Abboud PA, Kendall JL. Ultrasound guidance for vascular access. Emerg Med Clin North Am 2004;22: 749-73. [CrossRef] [PubMed]

22. Denys BG, Uretsky BF, Reddy PS. Ultrasound-assisted canulation of the internal jugular vein. A prospective comparison to the external landmark-guided technique. Circulation 1993;87:1557-62. [CrossRef] [PubMed]

23. Verghese ST, McGill WA, Patel RI, Sell JE, Midgley FM, Ruttimann UE. Ultrasound-guided internal jugular venous cannulation in infants: a prospective comparison with the traditional palpation method. Anesthesiology 1999;91:71-7. [CrossRef] [PubMed]

24. Hunter M. Peripherally inserted central catheter placement @ the speed of sound. Nutr Clin Pract 2007;22: 406-11. [CrossRef] [PubMed]

25. Karakitsos D, Labropoulos N, de Groot E, Patrianakos AP, Kouraklis G, Poularas J, et al. Real-time ultrasound-guided catheterisation of the internal jugular vein: a prospective comparison with the landmark technique in critical care patients. Crit Care 2006;10: R162. [CrossRef ] [PubMed]

26. Troianos CA, Kuwik RJ, Pasqual JR, Lim AJ, Odasso DP. Internal jugular vein and carotid artery anatomic relation as determined by ultrasonography. Anesthesiology 1996;85:43-8. [CrossRef] [PubMed]

27. Gordon AC, Saliken JC, Johns D, Owen R, Gray R. USguided puncture of the internal jugular vein: complications and anatomic considerations. J Vasc Interv Radiol 1998;9:333-8. [CrossRef] [PubMed]

28. Sulek CA, Gravenstein N, Blackshear RH, Weiss L. Head rotation duringinternal jugular vein cannulation and the risk of CA puncture. Anesth Analg 1996;82: 125-8. [CrossRef]

29. Blaivas M, Adhikari S. An unseen danger: frequency of posterior vesselwall penetration by needles during attempts to place internal jugular vein central catheters during ultrasound guidance. Crit Care Med 2009; 37:2345-9. [CrossRef] [PubMed]

30. Lieberman JA, Williams KA, Rosenberg AL. Optimal head rotation for internal jugular vein cannulation when relying on external landmarks. Anesth Analg 2004;99:982-8. [CrossRef] [PubMed]

31. Wang R, Snoey ER, Clements RC, Hern G, Price D. Effect of head rotation on vascular anatomy of the neck: an ultrasound study. J Emerg Med 2006; 31:283-6. [CrossRef] [PubMed]

32. Mallory DL, Shawker T, Evans RG, et al. Effects of clinical maneuvers on sonographically determined internal jugular vein size during venous cannulation. Crit Care Med 1990;18:1269-73. [CrossRef] [PubMed]

33. Calvert N, Hind D, McWilliams RG, Thomas SM, Beverley C, Davidson A. The effectiveness and costeffectiveness of ultrasound locating devices for central venous access: a systematic review and economic evaluation. Health Technol Assess 2003;7:1-84. [CrossRef] [PubMed]

34. Gualtieri E, Deppe SA, Slipperly ME, Thompson DR. Subclavian venous catheterization: greater success rate for less experienced operators using ultrasound guidance. Crit Care Med 1995;23:692-7. [CrossRef] [PubMed]

35. Bailey PL, Glance LG, Eaton MP, Parshall B, McIntosh S. A survey of the use of ultrasound during central venous catheterization. Anesth Analg 2007;104:4917. [CrossRef] [PubMed] 


\title{
ULTRAZVUČNO VOĐENA KANULACIJA CENTRALNIH VENA
}

\author{
Vladan Cvetanovići ${ }^{1}$ Ines Veselinović ${ }^{1}$, Vesna Dinićc ${ }^{1}$, Aleksandar Nikolić1 ${ }^{1}$ Milena Stojanović1, \\ Milica Marković1, Marko Gmijović 2
}

${ }^{1}$ Univerzitetski klinički centar Niš, Klinika za anesteziju i intenzivnu negu, Niš, Srbija

${ }^{2}$ Univerzitetski klinički centar Niš, Klinika za digestivnu hirurgiju, Niš, Srbija

Kontakt: Vladan Cvetanović

Bulevar dr Zorana Đinđića 48, 18000 Niš, Srbija

E-mail: vladan.cvetanovic@gmail.com

Kanulacija velikih venskih krvnih sudova predstavlja važan aspekt lečenja kritično obolelih, u smislu administracije tečnosti, lekova, parenteralne prehrane, kao i monitoringa. Konvencionalna tehnika, koja koristi površnu anatomiju i palpaciju kako bi se identifikovali veliki krvni sudovi pre kanulacije, bazira se na pretpostavljenoj lokalizaciji krvnih sudova, identifikaciji anatomskih obeležja na koži i slepoj inserciji igle do trenutka aspiracije krvi. Ova tehnika povezana je sa većom verovatnoćom neuspeha, zahteva veći broj pokušaja i izaziva više komplikacija. Ultrazvučno vođeno plasiranje centralnih venskih katetera obezbeđuje veći procenat ukupne uspešnosti, kao i uspešnosti prvog pokušaja kanulacije, a takođe obezbeđuje i brži vaskularni pristup, zadovoljstvo bolesnika i manje komplikacija.

Acta Medica Medianae 2021;60(3):72-79.

Ključne reči: ultrazvuk, centralni venski kateter, kanulacija 